
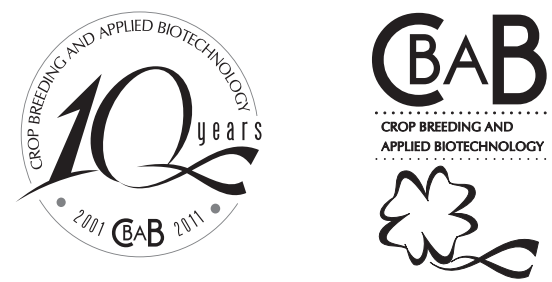

\title{
In vitro viability and preservation of pollen grain of kiwi (Actinidia chinensis var. deliciosa (A. Chev.) A. Chev)
}

\author{
Marcelo Borghezan ${ }^{1 *}$, Alan David Clauman ${ }^{1}$, Douglas André Steinmacher ${ }^{2}$, Miguel Pedro Guerra $^{1}$ and Afonso Inácio Orth ${ }^{1}$
}

Received 18 May 2011

Accepted 11 July 2011

\begin{abstract}
Kiwi is a dioecious plant species, requiring cross pollination for fruit production. The objective of this study was to evaluate the in vitro viability and shelf life of pollen grains of two kiwi varieties. Flowers of the cultivars Matua and Tomuri were collected and the pollen germinated in vitro, in culture medium containing agar (1\%), sucrose (0, 5, 10, 20 and $40 \%)$ and boric acid $\left(0\right.$ and $\left.50 \mathrm{mg} \mathrm{L}^{-1} \mathrm{H}_{3} \mathrm{BO}_{3}\right)$. Pollen grains were stored in a BOD incubator $\left(25.0^{\circ} \mathrm{C}\right)$, refrigerator $\left(4.0^{\circ} \mathrm{C}\right)$, freezer $\left(-18.0^{\circ} \mathrm{C}\right)$ and in liquid $\mathrm{N}_{2}\left(-196.0^{\circ} \mathrm{C}\right)$, and evaluated after $0,40,120,240$ and 365 days. The culture medium enriched with $12 \%$ sucrose and $50 \mathrm{mg}$ $\mathrm{L}^{-1} \mathrm{H}_{3} \mathrm{BO}_{3}$ was the most suitable. Pollen grains can be stored for a short period in the refrigerator or freezer, and cryopreserved for at least one year.
\end{abstract}

Key words: Tomuri, Matua, germination, cryopreservation.

\section{INTRODUCTION}

Kiwi (Actinidia chinensis var. deliciosa (A. Chev.) A. Chev.) is a fruit species native to the humid highlands of southern China and has spread out to several regions of the world (Ferguson 2007). The global production in 2007 exceeded 1.1 million tons and the world's leading producers are Italy, New Zealand and Chile (USDA 2011). In Brazil, production began in the mid-80s, and currently the production area is expanding. The states Rio Grande do Sul and Santa Catarina are the greatest producers. But still the supply does not meet the demand, requiring importation, mainly from Chile and Italy, to feed the markets (FEPAGRO 2011).
Kiwi is a dioecious species, with pale, straw-colored flowers, arranged singly or in groups, according to the variety. The flowers have five sepals and six petals and a diameter of about $3-5 \mathrm{~cm}$ when open. The female flowers have several functional stigmata in the central region, surrounded by anthers that produce sterile pollen. The male flowers consist of a rudimentary and non-functional pistil and a large number of stamens with anthers that produce viable pollen grains.

For fruiting, pollination is necessary, performed mainly by bees (Ferguson 2007). The traditional pollinating varieties (male) are Tomuri (late flowering) and Matua (early flowering), selected in New Zealand, and were classified in relation to the phenology of Hayward (female), the

\footnotetext{
${ }^{1}$ Universidade Federal de Santa Catarina, Departamento de Fitotecnia, CCA, Rod. Admar Gonzaga, 1346, Itacorubi, 88.040-900, Florianópolis, SC, Brazil. *E-mail: mborghezan@hotmail.com

${ }^{2}$ Instituto Biosomática, Rod. SP107, km 32, Centro, 13.825-000, Holambra, SP, Brazil
} 
leading fruit producing variety (Ferguson 2007, Novo et al. 2010).

Hand pollination is also possible, but expensive, while fertilization levels are lower and fruits smaller (Howpage et al. 1998). Alternatively, complementary pollination methods, using stored pollen grains that are applied to the flowers can ensure a satisfactory yield for this species (Abreu and Oliveira 2004). These methods may become important when the pollinator density is insufficient, as in recent cases of the collapse of bee colonies, reported in various parts of world (Williams and Osborne 2009, Ratnieks and Carreck 2010). In Brazil, fruit growers in the states of Santa Catarina and Rio Grande do Sul have reported significant losses of hives, affecting the pollination of orchards of various fruit species, e.g., apple.

Numerous studies on pollen grains are addressed in research on reproductive physiology (Falasca et al. 2010), conservation of germplasm (González-Benito et al. 2004), pollination and fruiting (Nunes et al. 2001, Bettiol Neto et al. 2009) and breeding (Cruz et al. 2008, Chagas et al. 2010, Novo et al. 2010). These in-depth studies about preservation, sustainability and growth of pollen grains are very useful. In breeding programs of pollinator (male) kiwi plants / varieties, with a view to the selection of alternative to traditional ones which would have high ability to produce pollen and flowering periods that coincide with the current fruitproducing varieties (Novo et al. 2010). Strategies for shortterm conservation of pollen grain may be required, although the viability may be reduced during storage of pollen grains, which could decrease the efficiency of pollination.

There are several methods for the evaluation of pollen viability, e.g., evaluation by acetic carmine staining (Domingues et al. 1999), incubation in Baker solution (Oliveira et al. 2001) or the germination test in culture medium (Franzon and Raseira 2006, Pio et al. 2007). The method of assessing the viability of pollen through germination in culture medium in vitro is practical and accurate (Einhardt et al. 2006). In vitro germination tests were performed for different fruit species, such as Annonaceae (Rosell et al. 1999, Bettiol Neto et al. 2009), citrus (Pio et al. 2007, Ramos et al. 2008), apple (Nunes et al. 2001, Dantas et al. 2005), passion fruit (Cruz et al. 2008) and native Myrtaceae (Franzon et al. 2005, Franzon and Raseira 2006). However, few studies have been published on in vitro viability and storage conditions of pollen grains of kiwi (Abreu and Oliveira 2004).

The objective of this study was to evaluate the in vitro viability and shelf life of pollen grain of two kiwi varieties (Actinidia chinensis var. deliciosa (A. Chev.) A. Chev.).

\section{MATERIAL AND METHODS}

Flowers of the male varieties (pollinators) Tomuri and Matua were selected from plants of the germplasm collection of the experimental stations of Epagri (Empresa de Pesquisa Agropecuária e Extensão Rural de Santa Catarina) located in Ituporanga and Videira, both in the state of Santa Catarina. Flowers were collected in preanthesis, stored in paper bags and transported in ice boxes to the laboratory.

From the collected flowers, the stamens were removed with a sieve. These were placed on paper towel to dry $\left(25 \pm 2{ }^{\circ} \mathrm{C}\right)$ for 72 hours for anther dehiscence and pollen collection. The pollen grains of both varieties were used to evaluate the in vitro germination. The preservation was assessed based on the pollen grains of the variety Tomuri.

For the in vitro germination test, semi-solid agar $(1 \%)$ was used. This medium was supplemented with different concentrations of sucrose $(0,5,10,20$ and $40 \%)$ and boric acid ( 0 and $50 \mathrm{mg} \mathrm{L}^{-1} \mathrm{H}_{3} \mathrm{BO}_{3}$ ). The culture medium was heated to near-boiling $\left(95^{\circ} \mathrm{C}\right)$, and then distributed on Petri dishes $\left(10 \mathrm{~mL} \mathrm{dish}^{-1}\right)$. The pollen grains of each variety were evenly distributed on the surface of the culture medium using a brush. The plates were stored at $25 \pm 2{ }^{\circ} \mathrm{C}$ for a period of 5 hours. The pollen grain viability was assessed under an optical microscope (Olympus BX40) with 100-fold amplification (Figure 1). The pollen grains were considered germinated whose pollen tube length was greater than the of the pollen grain diameter.

To assess the storage period, the pollen grains were placed in glass vials sealed with hygroscopic cotton or cryopreserved in polyethylene tubes (cryovials). Pollen grains were then stored in: a) $\mathrm{BOD}\left(25.0^{\circ} \mathrm{C}\right)$; b) refrigerator $\left.\left(4.0^{\circ} \mathrm{C}\right) ; \mathrm{c}\right)$ freezer $\left(-18.0^{\circ} \mathrm{C}\right)$; and d) cylinder containing liquid $\mathrm{N}_{2}\left(-196.0^{\circ} \mathrm{C}\right)$. Pollen viability was assessed after 0 , $40,120,240$ and 365 days of storage.

The pollen grains preserved in the different environments were germinated in semi-solid agar (1\%) plus sucrose $(10 \%)$ and boric acid $\left(50 \mathrm{mg} \mathrm{L}^{-1}\right)$. The pollen grains stored in $\mathrm{BOD}$, refrigerator and freezer were distributed directly on the surface of the culture medium. The pollen grains stored in liquid $\mathrm{N}_{2}$ were first shortly thawed, by immersing the cryotubes in water at $40{ }^{\circ} \mathrm{C}$ for 2 min.

The experimental design was completely randomized, consisting of nine replicates. Each evaluation was 


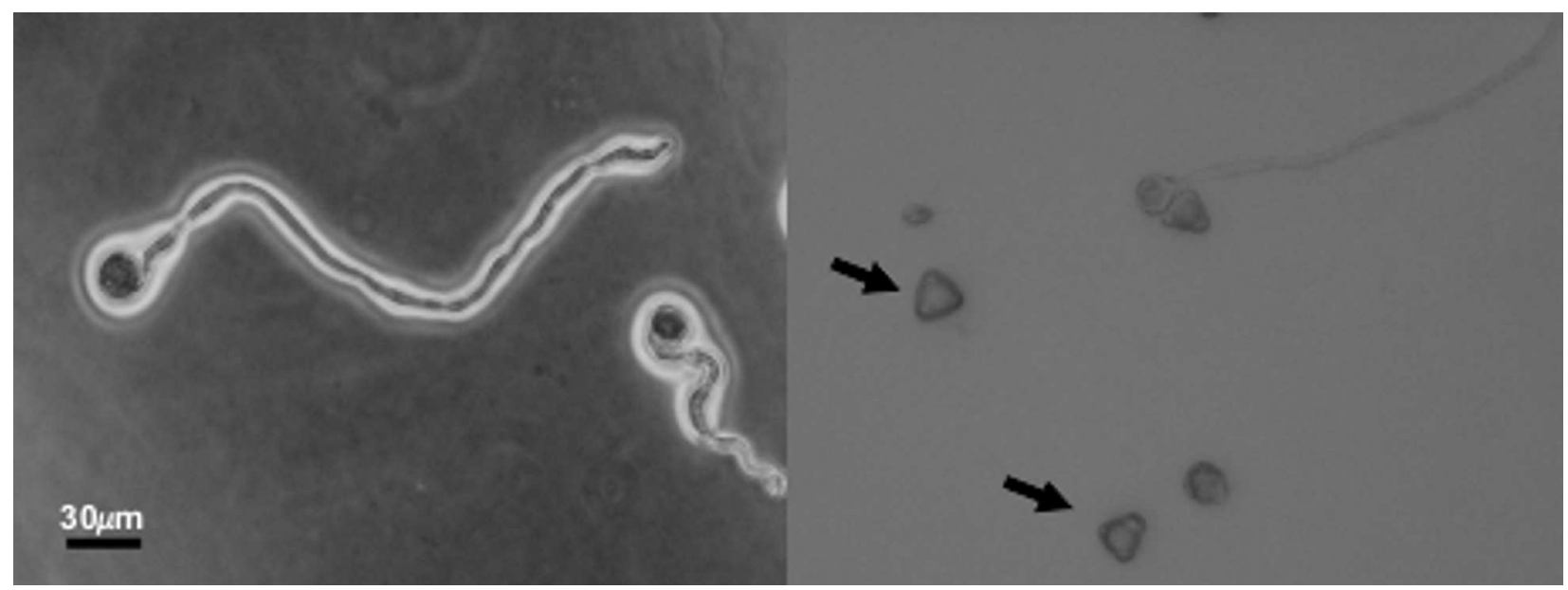

Figure 1. Kiwi pollen grain of the variety Tomuri in culture medium for in vitro germination test. Germinated (left) and non-germinated pollen grains (right).

performed on the basis of 100 pollen grains. The study of the culture medium for in vitro germination of pollen grains was structured in a $5 \times 2 \times 2$ factorial arrangement (sucrose $\mathrm{x}$ boric acid $\mathrm{x}$ variety). The study of pollen grain preservation was structured in a $4 \times 5$ factorial arrangement (environment $\mathrm{x}$ time). The data were subjected to residue analysis and test of homogeneity of variance (Levene's test). When necessary, data were transformed $(\sqrt{x+1})$. The data were subjected to the Student's t test ( $5 \%$ ) to evaluate the effect of boric acid and the variety. The effect of sucrose was performed using regression analysis. For storage, data were subjected to analysis of variance (ANOVA) and Tukey's mean separation (5\%).

\section{RESULTS AND DISCUSSION}

All factors (sucrose $\mathrm{x}$ boric acid $\mathrm{x}$ variety) and the interactions studied during germination of pollen grains under different culture media showed a significant effect $(\mathrm{p}<0.0000)$, except for the interaction boron $\mathrm{x}$ variety $(\mathrm{p}=$ $0.2425)$. Regarding the kiwi pollen grain preservation of the variety Tomuri, the factors environment ( $\mathrm{p}<0.0000$ ), storage time $(\mathrm{p}<0.0000)$ and interaction environment $\mathrm{x}$ time $(\mathrm{p}<0.0000)$ were significant.

The germination of pollen grains was significantly affected $(\mathrm{p}<0.0000)$ by the sucrose concentration in both varieties (Figure 2). In the culture medium free of sucrose and boric acid, the germination rate was below $15 \%$ for

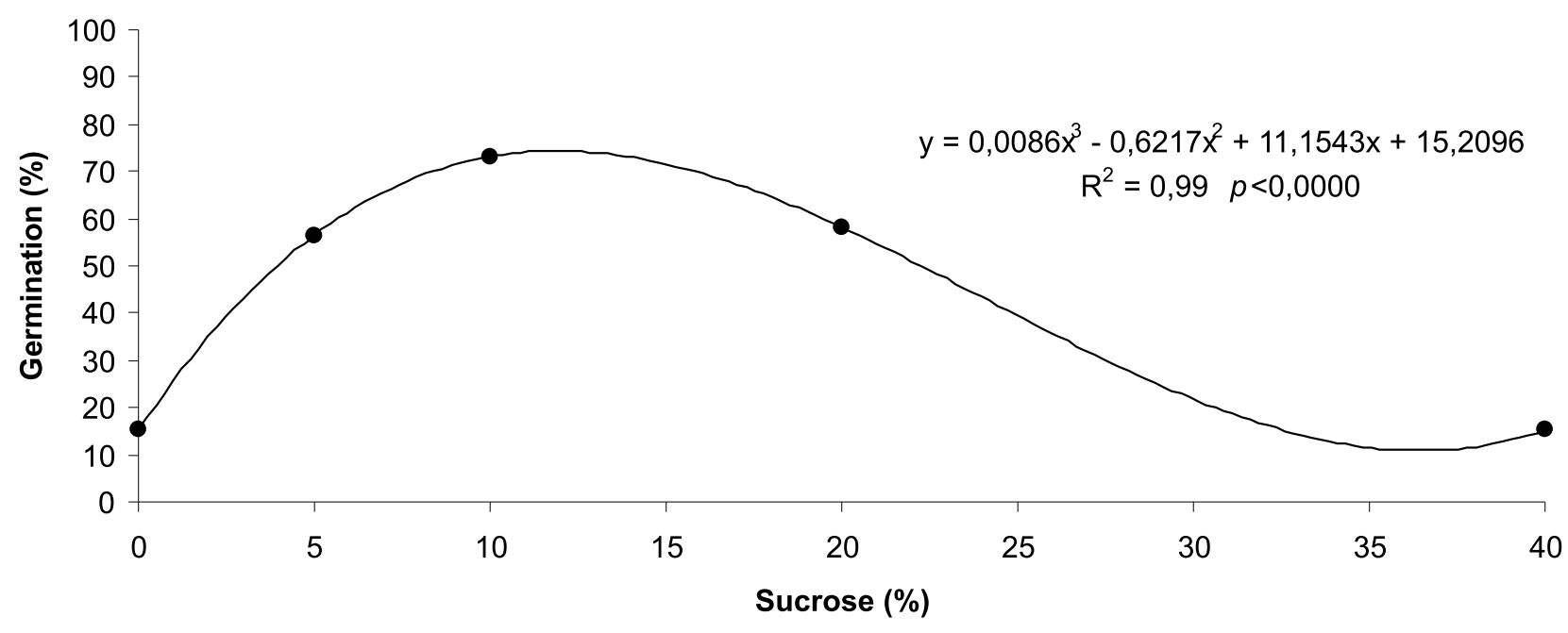

Figure 2. In vitro germination of kiwi pollen grain of the varieties Tomuri and Matua in culture medium with different sucrose concentrations. Values represent the mean of culture media with and without addition of boric acid. 
In vitro viability and preservation of pollen grain of kiwi (Actinidia chinensis var. deliciosa (A. Chev.) A. Chev.)

both varieties (Table 1). The culture medium supplemented with sucrose $(10 \%)$ resulted in the germination of more than $50 \%$ of the pollen grains.

The germination rates of pollen grains of both varieties were highest in response to sucrose concentrations between 5 and $20 \%$ (Figure 2 and Table 1). The polynomial model fit best $\left(\mathrm{R}^{2}=0.99, \mathrm{p}<0.0000\right)$ in the adjustment of the data variation (Figure 1). According to the estimated model, the sucrose concentration resulting in the highest germination rate was $12 \%$. It was estimated that in this culture medium, $74.4 \%$ of the pollen grains germinated.
These results are consistent with the $87 \%$ of viable Tomuri pollen grains reported by Abreu and Oliveira (2004) reported that. Assessing pollen germination of native Myrtaceae from southern Brazil, Franzon et al. (2005) and Franzon and Raseira (2006) observed a similar germination rate to that of kiwi, with 60 to $80 \%$ of germinated pollen grains in culture medium containing boric acid and $10 \%$ sucrose. Similar results were reported for germination of peach pollen (Einhardt et al. 2006). For Annonaceae species, Rosell et al. (1999) and Bettiol Neto et al. (2009) observed values below $40 \%$ of germinated pollen grains

Table 1. In vitro germination of kiwi pollen grain of the varieties Tomuri and Matua in culture medium with different concentrations of sucrose and boric acid

\begin{tabular}{|c|c|c|c|}
\hline $\begin{array}{l}\text { Culture medium } \\
\text { (\% sucrose / } \mathrm{mg} \mathrm{L}^{-1} \text { boric acid) }\end{array}$ & Tomuri & Matua & Mean \\
\hline $0 / 0$ & 0.3 & 14.7 & 7.6 \\
\hline $5 / 0$ & 38.4 & 68.8 & 53.7 \\
\hline $10 / 0$ & 52.6 & 83.9 & 68.2 \\
\hline $20 / 0$ & 33.4 & 83.7 & 58.6 \\
\hline $40 / 0$ & 0.0 & 7.3 & 3.7 \\
\hline Mean & 25.0 & 51.7 & $38.3 \mathrm{~b}$ \\
\hline $0 / 50$ & 16.4 & 29.2 & 22.8 \\
\hline $5 / 50$ & 50.7 & 68.2 & 59.4 \\
\hline $10 / 50$ & 70.4 & 85.6 & 78.0 \\
\hline $20 / 50$ & 36.7 & 78.8 & 57.8 \\
\hline $40 / 50$ & 0.0 & 53.8 & 26.9 \\
\hline Mean & 34.9 & 63.1 & $49.0 \mathrm{a}$ \\
\hline Mean of the varieties & $29.9 \mathrm{~B}$ & $57.4 \mathrm{~A}$ & - \\
\hline General mean & & 43.7 & \\
\hline CV $(\%)$ & & 4.9 & \\
\hline
\end{tabular}

${ }^{1}$ Means followed by different capital letters in the row and by lower case letters in the column indicate a significant difference by the $t$ Student's test, at $5 \%$ probability.

The addition of boric acid to the culture medium had a significant effect $(p=0.0440)$ on the germination of kiwi pollen grain (Table 1). When this component was not added to the culture medium, the germination rate was $38.3 \%$. Containing boric acid, the proportion of germinated pollen grains increased to $49.0 \%$. In culture medium supplemented with boric acid only, the germination rate ranged between 16 and 29\% for Tomuri and Matua, respectively. The germination rate of variety Tomuri was lower $(29.9 \%)$ than of Matua, at $57.5 \%$ ( $<$ < 0.0000). The culture medium containing $10 \%$ sucrose and $50 \mathrm{mg} \mathrm{L}^{-1}$ boric acid led to the germination of $70.4 \%$ of the pollen grains of Tomuri, while $85.6 \%$ of the Matua pollen germinated under this condition. in culture medium containing $5 \%$ sucrose.

A positive effect of the addition of boric acid and sucrose concentrations between 10 and $20 \%$ was also mentioned for apple (Nunes et al. 2001). Studying the germination of pear pollen grains, Chagas et al. (2010) also observed that the presence of boron in the culture medium was essential, while the addition of calcium nitrate had no significant effect.

The results of this study confirmed the descriptions of other authors (Nunes et al. 2001, Paiva Neto and Otoni 2003, Dantas et al. 2005, Franzon and Raseira 2006, Chagas et al. 2010), who reported the effect of carbohydrate as osmotic regulator between the pollen grain surface and the culture medium, apart from being an energy source for 
M Borghezan et al.

pollen tube growth. The presence of boron in the culture medium stimulated pollen germination, even in the absence of sucrose. Boron has multiple effects, as discussed by Herrera-Rodríguez et al. (2010), and its presence in the culture medium induces the formation of a sugar complex, and improving pollen germination (Okuse 1994). Boric acid also avoids the disruption of the pollen tube membranes (Ramos et al. 2008), promoting their growth (HerreraRodríguez et al. 2010).

At room temperature, Tomuri pollen grains rapidly lost viability (Figure 3). Pollen grains can be stored for a short period (40 days) in simple environments with reduced temperature (refrigerator or freezer). Under these conditions, the pollen grain viability decreased from $70 \%$ to around $40 \%$. After 120 days, about $35 \%$ of the pollen grains were still viable if stored at $-18{ }^{\circ} \mathrm{C}$, decreasing to $15 \%$ after 240 days. After 365 days of storage, the pollen grains had completely lost the ability to germinate in culture medium.

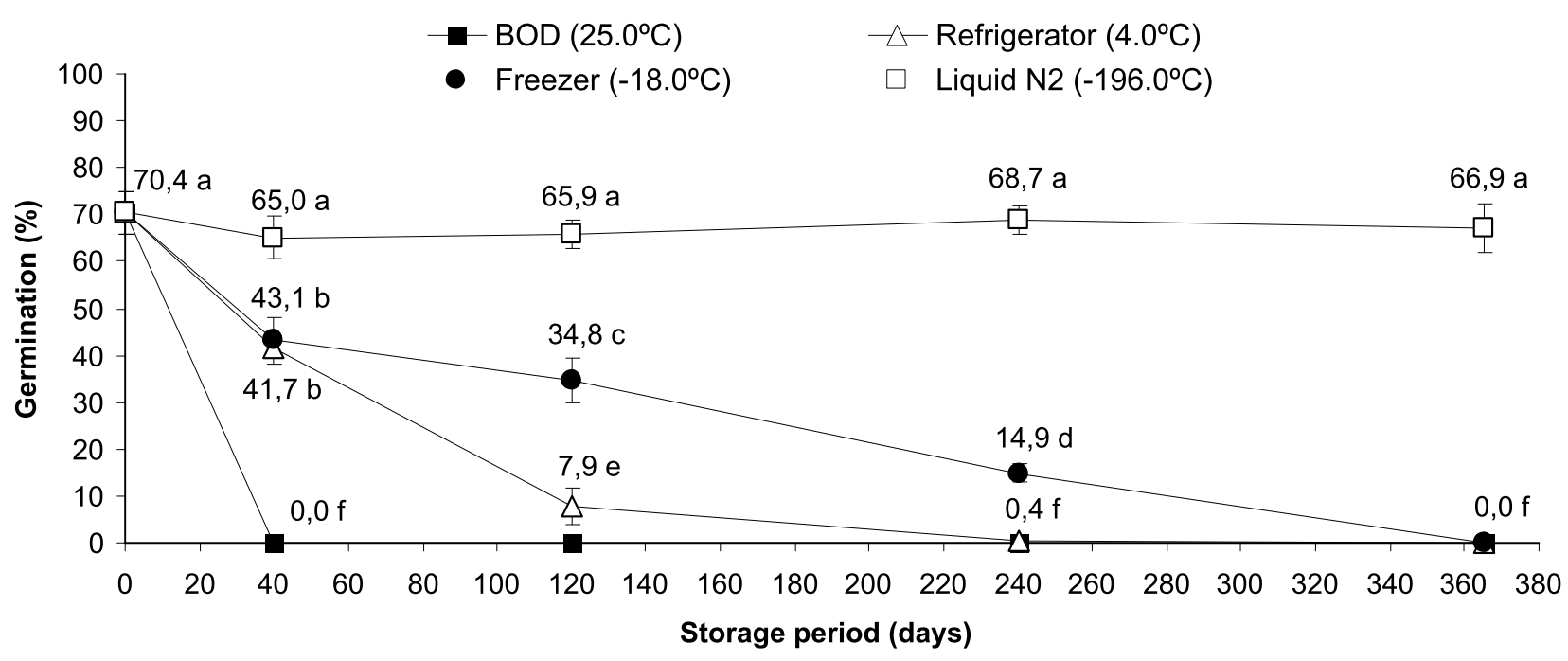

Figure 3. In vitro germination of kiwi pollen grain of the variety Tomuri, preserved in different environments. Means followed by different letters indicate significant differences by the Tukey test at 5\% probability. General Average $=30.5$. CV $(\%)=7.5$. Bars indicate standard deviation.

In cryopreservation, the pollen grain viability was maintained ( $70 \%$ ) during the evaluated storage period (Figure 3). The results of this study indicate that Tomuri pollen can be stored for more than a year.

The pollen grains of many species lose viability rapidly at room temperature (Pio et al. 2007, Cruz et al. 2008). However, low-temperature methods for pollen preservation have resulted in high viability levels in several studies (Oliveira et al. 2001, Franzon and Raseira 2006,
Bettiol Neto et al. 2009). For kiwi, longer conservation periods (up to 1 year) are needed for the supplementary pollination of varieties, which do not coincide in the flowering time, or for pollen required in breeding programs. Abreu and Oliveira (2004) observed high viability and germination of kiwi pollen grain after 12 months of storage; the fruits resulting from hand pollination had more seeds and were more regular in shape and size than fruits from natural pollination with fresh pollen. According to González-Benito et al. (2004), cryopreservation is a viable and economical technique for the conservation of genetic resources of vegetatively propagated plants, such as kiwi. The results in this study also indicated that the rapid thawing process allowed the maintenance of the pollen grain viability.

The high pollen germination rate in vitro in this study suggests that, as described elsewhere (Abreu and Oliveira 2004, Einhardt et al. 2006, Bettiol Neto et al. 2009), stored pollen can result in effective viability and fruit-set in the field. However, more studies on effective fruiting using preserved pollen grains still need to be expanded to kiwi.

The protocols for flower collection and handling were appropriate for the kiwi pollen grain conservation of the evaluated kiwi varieties. The germination rate of kiwi pollen grain was highest in the culture medium supplemented with sucrose $(12 \%)$ and boric acid $\left(50 \mathrm{mg} \mathrm{L}^{-1}\right)$. The pollen grains used for pollination in the same growth cycle can be stored in the refrigerator or freezer. The storage conditions 
In vitro viability and preservation of pollen grain of kiwi (Actinidia chinensis var. deliciosa (A. Chev.) A. Chev.)

in liquid nitrogen (cryopreservation) maintained the viability of kiwi pollen grain for up to one year.

\section{ACKNOWLEDGEMENTS}

The authors are indebted to the researchers of the Empresa de Pesquisa Agropecuária e Extensão Rural de
Santa Catarina (Epagri) in Ituporanga/SC, João Favorito Debarba, and in Videira/SC, Ênio Schuck, for granting the permission to use flowers from the kiwi cultivar collection.

\section{Viabilidade in vitro e conservação de grãos de pólen de quiwi (Actinidia chinensis var. deliciosa (A. Chev.) A. Chev.)}

RESUMO - O quiwizeiro é uma espécie dióica, necessitando de polinização para a produção dos frutos. O objetivo deste trabalho foi avaliar a viabilidade in vitro e o tempo de conservação dos grãos de pólen de duas variedades de quiwi. Foram coletadas flores das variedades Matua e Tomuri. A germinação in vitro foi realizada em meio de cultura, contendo ágar ( $1 \%)$, sacarose ( $0,5,10$, 20 e $40 \%$ ) e ácido bórico ( $\left(0\right.$ e $50 \mathrm{mg} \mathrm{L} \mathrm{L}^{-1}$ de $\left.\mathrm{H}_{3} \mathrm{BO}_{3}\right)$. Os grãos de pólen foram mantidos em $\mathrm{BOD}\left(25,0{ }^{\circ} \mathrm{C}\right)$, geladeira $\left(4,0^{\circ} \mathrm{C}\right)$, freezer $\left(-18,0^{\circ} \mathrm{C}\right)$ e em $N_{2}$ líquido $\left(-196,0^{\circ} \mathrm{C}\right)$. As avaliações foram realizadas aos $0,40,120,240$ e 365 dias de conservação. $O$ meio de cultura mais adequado foi suplementado com $12 \%$ de sacarose e $50 \mathrm{mg} \mathrm{L}^{-1}$ de $\mathrm{H}_{3} \mathrm{BO}_{3}$. Os grãos de pólen podem ser conservados por curto período em geladeira ou freezer, e por um ano, sob criopreservação.

Palavras-chave: Tomuri, Matua, germinação, criopreservação.

\section{REFERENCES}

Abreu I and Oliveira M (2004) Fruit production in kiwifruit (Actinidia deliciosa) using preserved pollen. Australian Journal of Agricultural Research 55: 565-569.

Bettiol Neto JE, Nero M, Kavati R and Pinto-Maglio CAF (2009) Viabilidade e conservação de pólen de três anonas comerciais. Bragantia 68: $825-837$.

Chagas EA, Pio R, Chagas PC, Pasqual M and Bettiol Neto JE (2010) Composição do meio de cultura e condições ambientais para germinação de grãos de pólen de porta-enxertos de pereira. Ciência Rural 40: 261-266.

Cruz TV, Souza MM, Roza FA, Viana AJC, Belo GO and Fonseca JWS (2008) Germinação in vitro de grãos de pólen em Passiflora suberosa L. para sua utilização em hibridação interespecífica. Revista Brasileira de Fruticultura 30: 875-879.

Dantas ACM, Peixoto ML, Nodari RO and Guerra MP (2005) Viabilidade do pólen e desenvolvimento do tubo polínico em macieira (Malus spp.). Revista Brasileira de Fruticultura 27: 356-359.

Domingues ET, Tulmann Neto A and Teófilo Sobrinho J (1999) Viabilidade do pólen em variedades de laranja doce. Scientia Agrícola 56: 265-272.

Einhardt PM, Correa ER and Raseira MCB (2006) Comparação entre métodos para testar a viabilidade de pólen de pessegueiro. Revista Brasileira de Fruticultura 28: 5-7.
Falasca G, Franceschetti M, Bagni N, Altamura MM and Biasi R (2010) Polyamine biosynthesis and control of the development of functional pollen in kiwifruit. Plant Physiology and Biochemistry 48: 565-573.

FEPAGRO - Fundação Estadual de Pesquisa Agropecuária (2011) Kiwi é alternativa para agricultores da Serra Gaúcha. Available at http://www.fepagro.rs.gov.br Accessed on Jan. 15, 2011.

Ferguson AR (2007) The need for characterization and evaluation of germplasm: kiwifruit as an example. Euphytica 154: 371382 .

Franzon RC, Corrêa ER and Raseira MCB (2005) In vitro pollen germination of feijoa (Acca sellowiana (Berg) Burret). Crop Breeding and Applied Biotechnology 5: 229-233.

Franzon RC and Raseira MCB (2006) Germinação in vitro e armazenamento do pólen de Eugenia involucrata DC (Myrtaceae). Revista Brasileira de Fruticultura 28: 18-20.

Gonzalez-Benito ME, Clavero-Ramírez I and López-Aranda JM (2004) The use of cryopreservation for germplasm conservation of vegetatively propagated crops. Spanish Journal of Agricultural Research 2: 341-351.

Herrera-Rodríguez MB, Gonzáles-Fontes A, Rexach J, CamachoCristóbal JJ, Maldonado JM and Navarro-Gochicoa MT (2010) Role of boron in vascular plants and response mechanisms to boron stresses. Plant Stress 4: 115-122. 
M Borghezan et al.

Howpage D, Vithanage V and Spooner-Hart R (1998) Pollen tube distribution in the kiwifruit (Actinidia deliciosa A. Chev. C. F. Liang) pistil in relation to its reproductive process. Annals of Botany 81: 697-703.

Nunes JCO, Dantas ACM, Pedrotti EL, Orth AI and Guerra MP (2001) Germinação de pólen in vitro e receptividade do estigma em macieira cvs. Fuji e Golden Delicious. Revista Brasileira de Fruticultura 23: 35-39.

Novo M, Romo S, Rey M, Prado MJ and González MV (2010) Identification and sequence characterization of molecular markers polymorphic between male kiwifruit (Actinidia chinensis var. deliciosa (A. Chev.) A. Chev.) accessions exhibiting different flowering time. Euphytica 175: 109-121.

Okuse I (1994) Influences of some mineral ions on pollen germination and pollen tube growth in Starking Delicious apple (Malus pumila). Bulletin of the Faculty of Agriculture 57: 45-54.

Oliveira MSP, Maués MM and Kalume MAA (2001) Viabilidade de pólen in vivo e in vitro em genótipos de açaizeiro. Acta Botânica Brasilica 15: 27-33.
Paiva Neto VB and Otoni WC (2003) Carbon sources and their osmotic potential in plant tissue culture: does it matter? Scientia Horticulturae 97: 193-202.

Pio LAS, Ramos JD, Pasqual M, Junqueira KP, Santos FC and Rufini JCM (2007) Viabilidade do pólen de laranjas doces em diferentes condições de armazenamento. Ciência e Agrotecnologia 31: $147-153$.

Ramos JD, Pasqual M, Salles LA, Chagas EA and Pio R (2008) Receptividade do estigma e ajuste de protocolo para germinação in vitro de grãos de pólen de citros. Interciência 33: 51-55.

Ratnieks FLW and Carreck NL (2010) Clarity on honeybee collapse? Science 327: 152-153.

Rosell P, Herrero M and Galán Saúco M (1999) Pollen germination of cherimoya (Annona cherimola Mill.). In vivo characterization and optimization of in vitro germination. Scientia Horticultura 81: 251-265.

USDA - United States Department of Agriculture. Kiwifruit situation for selected countries. Available at http://www.ers.usda.gov/data/ fruitvegphyto/Data/fr-kiwi.xls> Accessed on Jan. 15, 2011.

Williams PH and Osborne JL (2009) Bumblebee vulnerability and conservation world-wide. Apidologie 40: 367-387. 